\title{
8. NEOGENE SILICOFLAGELLATES OF THE EASTERN EQUATORIAL PACIFIC, DEEP SEA DRILLING PROJECT HOLE 503A ${ }^{1}$
}

\author{
David Bukry, U.S. Geological Survey, Scripps Institution of Oceanography, La Jolla, California
}

\begin{abstract}
Neogene silicoflagellates are especially abundant and well preserved in Deep Sea Drilling Project (DSDP) Miocene Cores 30 to 54 of DSDP Hole 503A; Pliocene assemblages in Cores 12 to 30 are less abundant and contain increased numbers of solution-thinned specimens. The Asperoid/Fibuloid ratio of Dictyocha reversed six times during the late Miocene, making questionable the placement of the $D$. brevispina to the $D$. fibula Zone boundary. Transitional forms in the late Miocene D. neonautica lineage are identified. An associated population of Mesocena diodon nodosa may have evolved from the $D$. neonautica transitional group. Several recently described guide species for the Pliocene first occur in Pliocene Cores 12 to 30, including D. angulata, D. delicata var. bisecta, D. ornata africana, and D. perlaevis flexatella. The first $D$. stapedia stapedia, marking the base of the $D$. stapedia Zone, occurs in the middle of the Pliocene, helping to establish the age of the zone base. Relative paleotemperature values for silicoflagellates are typically high; brief maximum coolings occur only in the upper Miocene interval between Cores 31 to 37, in and near the upper D. neonautica Subzone.

Six new silicoflagellate taxa are described, including $D$. arbutusensis Bukry, n. sp., $D$. perfecta Bukry, n. sp., $D$. transenna Bukry, n. sp., Distephanus crux carolae Bukry, n. subsp., D. speculum bispicatus Bukry, n. subsp., and $D$. speculum tenuis Bukry, $\mathrm{n}$. subsp.
\end{abstract}

\section{INTRODUCTION}

DSDP Hole 503A is near DSDP Site 83, Leg 9, which, by rotary-coring techniques, recovered diverse, well-preserved assemblages of Neogene silicoflagellates in the eastern equatorial Pacific. To overcome the drilling disturbance in the original coring of this useful stratigraphic reference site, Glomar Challenger, using the new DSDP hydraulic piston corer (HPC), recored the area during Leg 68 at Site 503. Preserving the detail of the original stratigraphic succession allows a more confident analysis of stratigraphic sequences as well as the detection of evolution among taxa. Relations between taxa-suggested from rotary-cored strata of previous sites-can be tested.

Silicoflagellate assemblages were documented by light microscope counts of 100 to 300 specimens per sample, using acid residue strewn slides viewed at magnifications of $250 \mathrm{X}$ or $600 \mathrm{X}$. Observations of 14,000 specimens were completed over a single three-week period. These observations are discussed in the sections on zonation, paleotemperature, evolution, and taxonomy.

\section{NEOGENE ZONATION}

The warm-water silicoflagellate zonation (Bukry, 1981a) is applied to the assemblages from Hole 503A (Fig. 1). Several newly described taxa from Site 495 off Guatemala occur at Hole 503A and assist in local correlation. New zonal details are revealed for the expanded upper Miocene section through the high diversity of the assemblages and the use of the HPC for undisturbed

\footnotetext{
${ }^{1}$ Prell, W. L., Gardner, J. V., et al., Init. Repts. DSDP, 68: Washington (U.S. Govt. Printing Office).
}

sediment recovery. For example, a suspected two-part division of the $D$. neonautica Subzone is confirmed by the first occurrence of $D$. neonautica well below the range of $D$. neonautica var. cocosensis. Futhermore, there are several reversals and different occurrence times for the reversal in the Asperoid/Fibuloid dominance (Bukry and Foster, 1973; Bukry, 1981a, 1981b) through the upper Miocene section of Hole 503A. This suggests that even in tropical areas, for which the Asperoid/ Fibuloid ratio shift was selected as a zonal boundary criterion, there is need of a more consistent biostratigraphic guide.

Brief characterizations of zones and subzones in Hole 503A (Figs. 2A-2C), from youngest to oldest, follow.

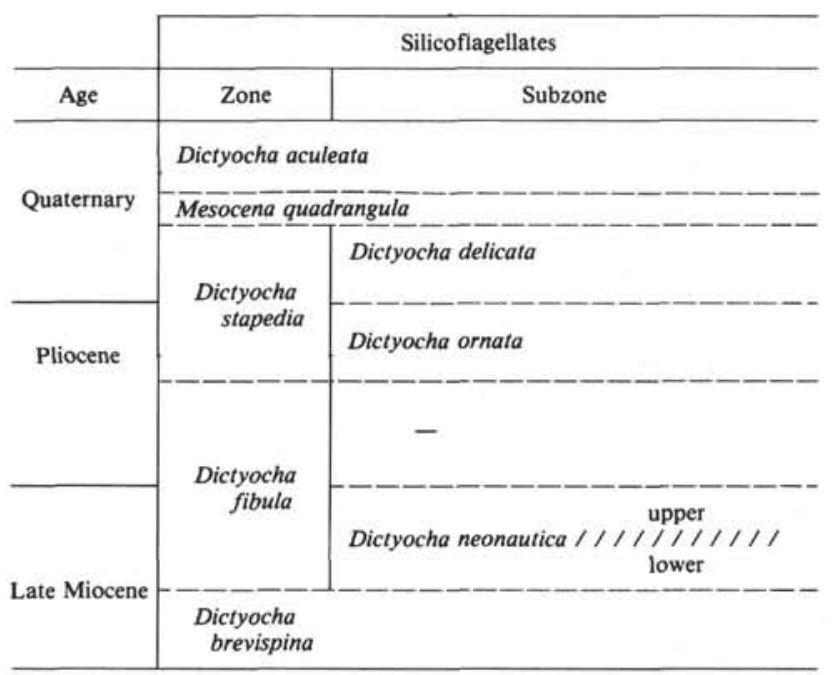

Figure 1. Low-latitude silicoflagellate zonal sequence applied to Hole 503A is from Bukry (1981a). 


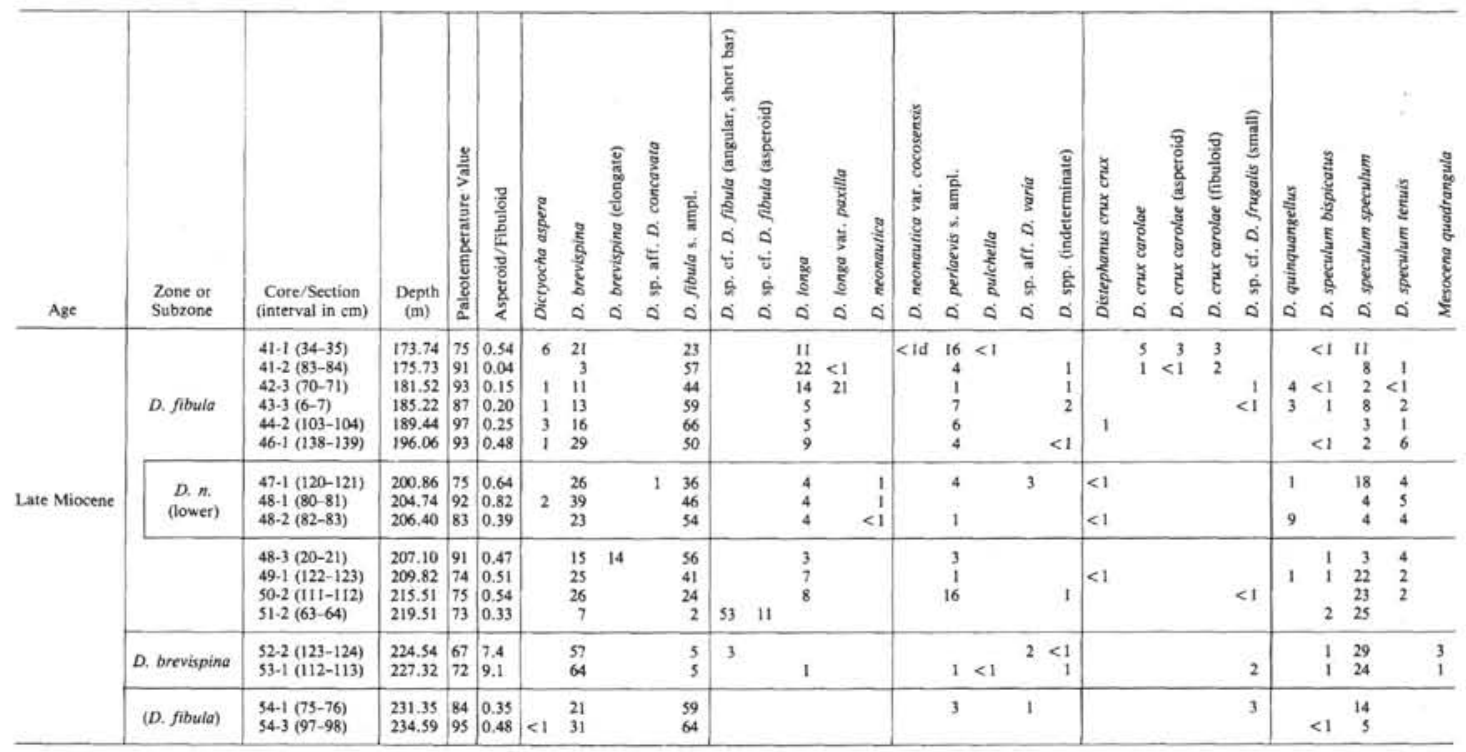

Figure 2A. Neogene sucoflagellates trom Cores 41 to 54 in Hole JUSA recorded as percentage calculated from counts of 300 specimens for each sample. Asperoid/Fibuloid ratio shows three reversals. $d=$ probable displaced specimen from higher core.

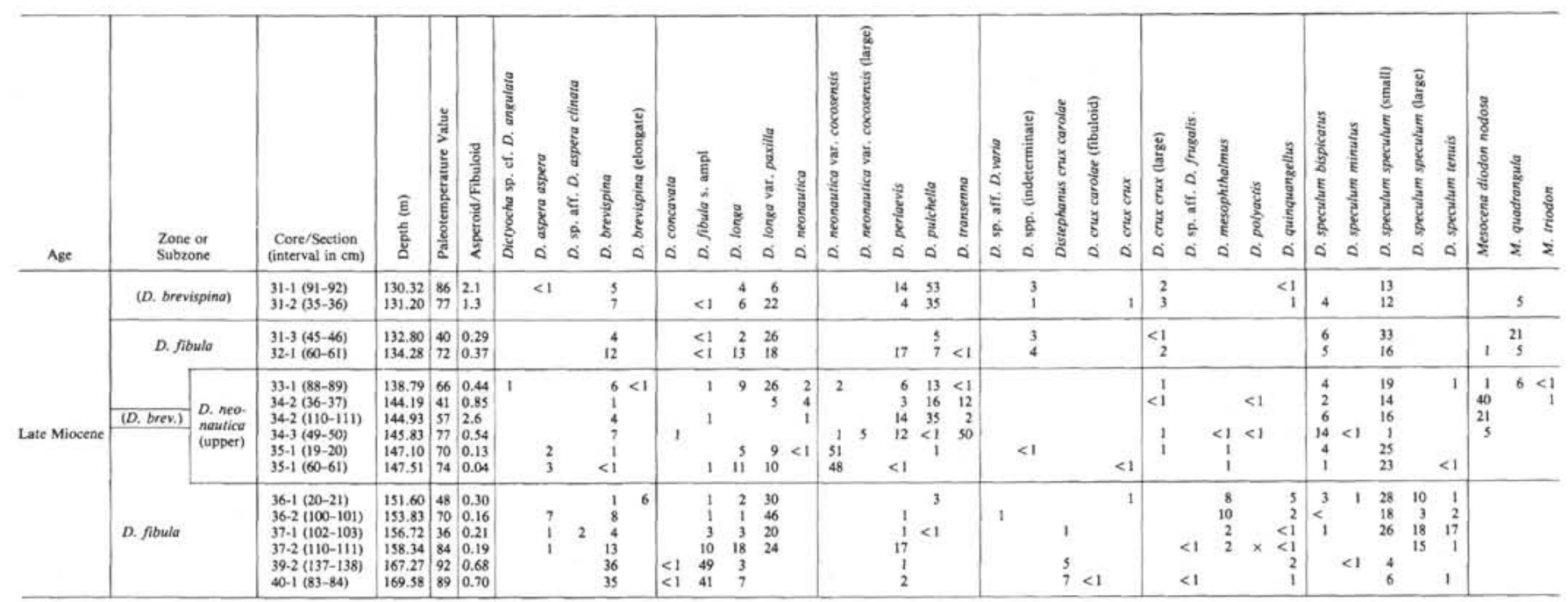

Figure 2B. Neogene silicoflagellates from Cores 31 to 40 in Hole 503A recorded as percentage calculated from counts of 300 specimens for each sample. Asperoid/Fibuloid ratio shows three reversals. $\mathrm{x}=$ recorded after count.

\section{Dictyocha stapedia Zone}

The first definite population of Dictyocha sp. aff. $D$. stapedia stapedia with spired bar and slightly asymmetric struts occurs in upper lower Pliocene Sample 503A$19-2(124-125 \mathrm{~cm})$. D. stapedia stapedia with definitely offset struts and more angular ring first occurs in Sample 503A-14-3 $(64-65 \mathrm{~cm})$ and is consistently present above that level. The base of the zone is identified at 503A-19-2 (124-125 cm), because the ring of $D$. sp. aff. D. stapedia stapedia is slightly less lobate than associated specimens of its (probable) spired precursor, D. longa var. paxilla. Thus I use the first common $D$. sp. aff. $D$. stapedia stapedia for the base of the D. stapedia Zone.

Two noteworthy new species events for the eastern equatorial Pacific occur near the lower boundary of the
D. stapedia Zone of Hole 503A in the same sequence as at Site 495 to the north. The first appearance and acme of Dictyocha angulata occur just below the $D$. stapedia zone at both locations. Similarly, the first appearance and acme of Dictyocha delicata var. bisecta occurs at and just above the base of the $D$. stapedia Zone but just below the first $D$. ornata africana.

\section{Dictyocha ornata Subzone}

Dictyocha ornata africana is concentrated $(10 \%)$ in a single sample, 503A-14-2 (21-22 cm). A minor occurrence $(2 \%)$ of $D$. sp. aff. D. ornata ornata some 4 meters higher provides the upper limit of the $D$. ornata Subzone (Bukry, 1981a). Other significant events within the subzone, which also correlate with Site 495 assemblages, are the appearance of $D$. perlaevis flexatella and 


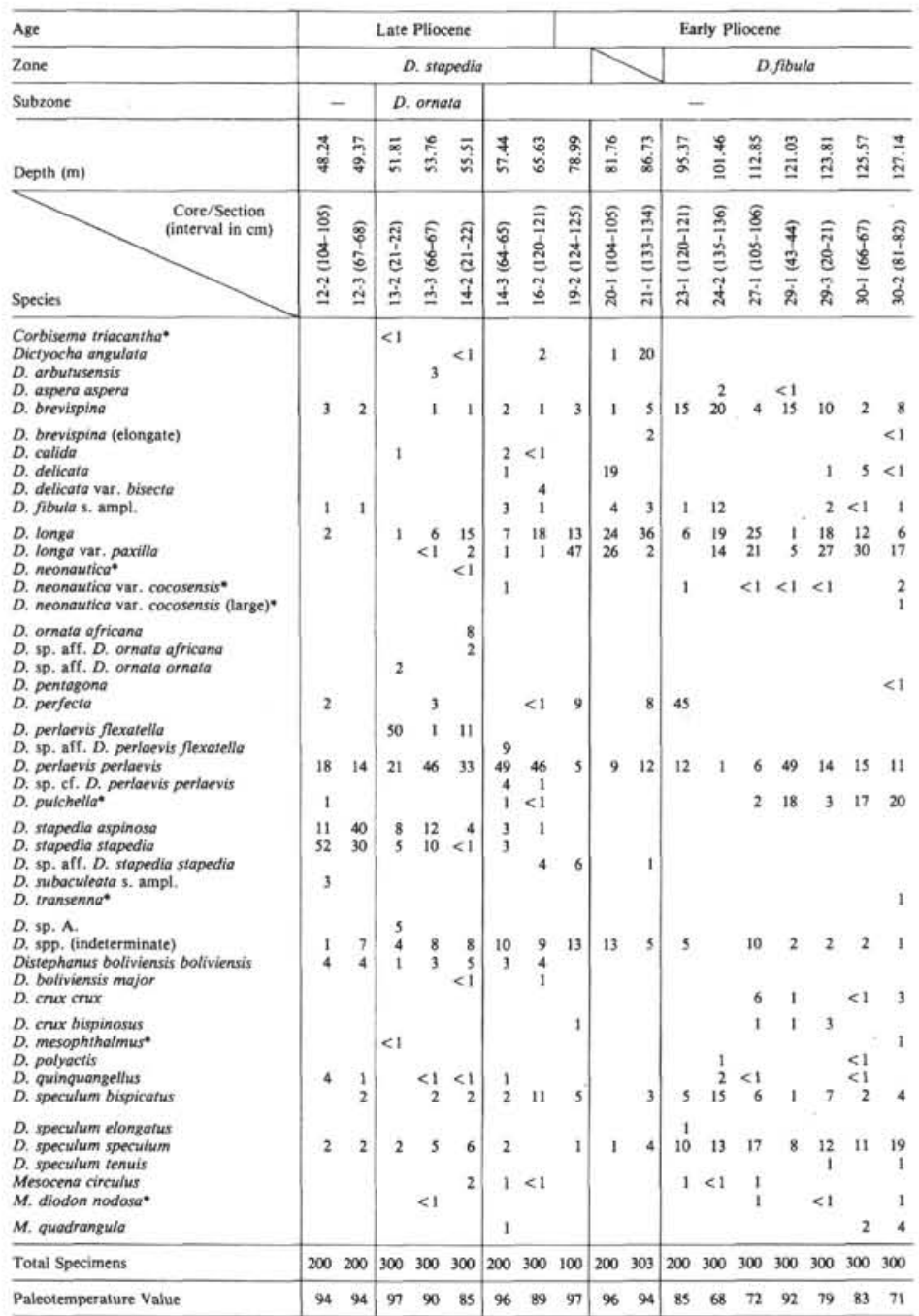

Figure 2C. Neogene silicoflagellates from Cores 12 to 30 in Hole 503A recorded in percentages. Asperoid/Fibuloid ratios range from 0.00 to 0.77 and show no reversals. * = minor occurrences probably resulting from reworking.

the last common $D$. longa. The overlying $D$. delicata Subzone of the $D$. stapedia Zone was not identified at Hole $503 \mathrm{~A}$, possibly because no samples were studied above Core 12. The oldest specimens of $D$. delicata at Hole 503A are from the early Pliocene. This suggests a nonuniform distribution for this guide species below the D. delicata Subzone.

\section{Dictyocha fibula Zone}

This zone is bounded by the Asperoid/Fibuloid reversal of Dictyocha at the base and by the first $D$. stapedia stapedia at the top (Bukry, in press a). Unfortunately, detailed counts at Hole 503A show six reversals of the Asperoid/Fibuloid ratio through the prescribed general interval for the $D$. fibula Zone. Possible substitute criteria, such as the first $D$. longa or first $D$. neonautica, lack the recognition clarity of the ratio criterion, because instead of being identified by simple counts of unequivocal morphologic contrast they would be based on more subjective taxonomic interpretations. But given the distribution of the ratio reversals through the whole Miocene portion of the zone, the opportunity for miscorrelation, particularly of isolated samples, argues for one of the taxonomic first occurrence options. Further study is needed for the best selection.

\section{Dictyocha neonautica Subzone}

The elongate species Dictyocha neonautica appears near the base of the Amaurolithus primus Subzone (CN9b) of coccoliths in the upper Miocene. D. neonautica var. cocosensis appears at a higher level in Subzone $C N 9 b$. Therefore the $D$. neonautica Subzone can be divided into two separate parts: a lower part identified by the initial appearance and presence of $D$. neonautica and an upper part identified by the initial appearance and natural, unreworked range of $D$. neonautica var. cocosensis. The 53-meter interval between these ranges in Hole 503A would have to be assigned to a more broadly defined zone. The combined problems of the Asperoid/Fibuloid reversals and two-part $D$. neonautica se- 
quence make dubious any correlation of isolated samples from the upper Miocene. A through-going species, in the manner of $D$. longa (Figs. 2A, 2B), would be most helpful for isolated samples.

\section{Dictyocha brevispina Zone}

The asperoid species Dictyocha brevispina and $D$. pulchella are more abundant than fibuloid species such as D. fibula s. ampl., D. longa s. ampl., and D. perlaevis s. ampl., in Cores $31,34,52$, and 53. Higher and lower cores have fibuloid species dominant. This distribution shows the biostratigraphic weakness of a nontaxonomic criterion for zonal definition. Even the deepest $D$. brevispina Zone samples are underlain by imputedly younger $D$. fibula Zone samples in Core 54 (Fig. 2A).

The general dominance of asperoid taxa in lower upper Miocene and middle Miocene assemblages makes the reversal to generally fibuloid dominant Dictyocha assemblages in the upper upper Miocene and Pliocene a widely useful stratigraphic approximation. But, in detail, the ratio relationship fails as a zonal criterion. When reversals occur near the base of a section, such as in Hole 503A, there is no way of ascertaining biostratigraphically if the reversal represents a local anomaly or a regionally significant event.

\section{RELATIVE PALEOTEMPERATURE VALUES $(T s)$}

A simple relation $T s=X w+0.5 X t$ provides a quantitative basis to compare the paleotemperature values for upper Cenozoic silicoflagellate assemblages along the Pacific Coast (Bukry, 1981b). In Hole 503A the percentages of warm-water taxa $(X w)$ Corbisema and Dictyocha far outnumber the percentages of temperate-water taxa ( $X t)$ Distephanus (quadrate only). Except for the interval at and near the upper Dictyocha neonautica Subzone, the paleotemperature values are routinely high with only minor variation. In contrast, the values for the upper D. neonautica Subzone interval in Cores 31 to 37 show substantial and more frequent fluctuations. The lowest values of Cores $36,40,41$, and 48 are interspersed with warmer values from 66 to 84 . It is noteworthy that the only occurrence of North Pacific, late Miocene temperate species Dictyocha sp. aff. D. aspera clinata occurs with the lowest paleotemperature value $(T s=36)$ of Hole 503A in Sample 503A-37-1 (102-103 $\mathrm{cm})$. This sample contains the maximum abundance of the predominantly cool-water Distephanus speculum plexus $(62 \%)$.

At more northerly DSDP Sites 471 and 495 , the upper D. neonautica Subzone has low TS values (48 to 61 and 62 , respectively). These values are based on fewer samples, but they corroborate a regional cooling for that time period. The average $T s$ value within the upper $D$. neonautica Subzone $(9 \mathrm{~m})$ in Hole 503A is 64. Average values for an equal 9-meter interval below is $T s=60$ and above $T s=69$. Compared to other intervals, these three 9-meter intervals are the coolest; all other intervals are considerably higher. Therefore the evolutionary and biostratigraphic events that distinguish the upper $D$. neonautica Subzone interval are probably the result of a general climatic cooling in the eastern North Pacific in the late late Miocene.

\section{SILICOFLAGELLATE EVOLUTION}

Undisturbed sediment from the HPC cores of Hole 503A permits the proposal of two evolutionary sequences in the Miocene and Pliocene. A sequence of appearances among fibuloid taxa suggests that Dictyocha fibula was the source for $D$. longa in the upper Miocene. The spired variety, $D$. long $a$ var. paxilla, appeared higher in the Miocene and was the first spired Dictyocha of the Neogene. The first occurrence of $D$. stapedia stapedia in the middle of the Pliocene is related to $D$. longa var. paxilla by transition forms $(D$. sp. aff. $D$. stapedia stapedia) showing slight asymmetry of struts and slightly lobed ring in Cores 16 and 19. The first $D$. stapedia stapedia s. str. is in Core 14. Later forms derived from $D$. stapedia stapedia probably include spired and asymmetric-strut taxa $D$. subaculeata (Core 12) and younger D. aculeata (absent in Cores 12 to 54).

A development of naviculopsoid variants of $D$. brevispina in the late Miocene has been well described by Deflandre (1941). The oceanwide occurrence of two such forms, $D$. neonautica and $D$. neonautica var. cocosensis, has been formalized into a biostratigraphic subzone (Bukry, 1981a) which occurs in Hole 503A. D. neonautica, the older of the two, is the most elongate with L/W $\simeq 4$. Its first appearance in Core 48 is preceded in the same core by an unusually elongate population of $D$. brevispina $(\mathrm{L} / \mathrm{W} \simeq 1.5)$. This may not be a direct transitional form, but it does show a coincidental tendency to major-axis lengthening and to reduction of minor-axis portals.

After briefly establishing a low-frequency presence of $<1 \%$ to $1 \%, D$. neonautica disappeared until $D$. neonautica var. cocosensis appeared higher in the Miocene. It is unclear whether $D$. neonautica persisted as a sparse background species to be the source for $D$. neonautica var. cocosensis or whether the higher specimens are of a secondary origin from $D$. brevispina. In any event, the evolution and large abundance of $D$. neonautica var. cocosensis are consequential in Hole 503A, and Dictyocha transenna first appears immediately after the acme of $D$. neonautica var. cocosensis.

Dictyocha transenna appears to be an extreme form that could be derived from $D$. neonautica by migration of the bar to one end of the ring. Since some specimens are slightly lobed and more elongate, the bar could also be a remnant from a fibuloid Dictyocha species source. Two specimens similar to D. transenna, from Sample 504-53-1 (26-27 cm), have two small spines at the sides of the ring at the minor axis, further suggesting a Dictyocha source. Whether $D$. transenna is derived directly from a fibuloid source or indirectly through $D$. neonautica var. cocosensis from an asperoid Dictyocha, the significant evolutionary aspect of $D$. transenna is that by abundance, morphology, and stratigraphy, it is the most likely source for the Mesocena diodon nodosa specimens in Hole 503A. This relation means that $M$. diodon nodosa is polyphyletic, because its earlier appear- 
ances in the middle and late Miocene of Leg 63 (Bukry, 1981b) are associated with other Mesocena taxa and not with $D$. transenna.

\section{SYSTEMATIC PALEONTOLOGY OF NEW TAXA Genus DICTYOCHA Ehrenberg, 1837 \\ Dictyocha arbutusensis Bukry, n. sp. (Plate 1, Figs. 5-9)}

Description. Dictyocha arbutusensis has an elongate ring lacking minor-axis spines and has a moderate fibuloid bar. The sides of the ring are slightly convex at the minor-axis portals and are inclined toward the apices. Pikes are missing or are only small vestiges located under the strut-ring junction. The $\mathrm{L} / \mathrm{W}$ ratio for the ring ranges from 2.8 to 3.4 .

Remarks. D. arbutusensis is distinguished from $D$. fibula f. rectangularis (see Ichikawa, 1973) by a lobed and inclined ring instead of a parallel-sided oblong ring. The large size and absence of minor-axis spines distinguish it from other Dictyocha species.

Occurrence. $D$. arbutusensis is a minor species in upper Pliocene Sample 503A-13-3 $(66-67 \mathrm{~cm})$. It occurs within the ranges of $D$. ornata $\mathrm{s}$. ampl. and $D$. perlaevis flexatella.

Size. Maximum inner diameter 45 to $65 \mu \mathrm{m}$ (holotype $59 \mu \mathrm{m}$ ),

Holotype. USNM 313051 (Plate 1, Fig. 5).

Isotypes. USNM 313052 to 313055 .

Type locality. Eastern equatorial Pacific, DSDP Sample 503A-13$3(66-67 \mathrm{~cm})$.

\section{Dictyocha perfecta Bukry, n. sp.}

(Plate 3, Figs. 5-10)

Description. Dictyocha perfecta is large and has a moderate fibuloid bar. The struts diverge from the bar at a sharp angle and are not elevated very high above the ring. Pikes are indistinct; if present they are vestiges below the strut-ring junction. The ring is slightly lobed and elongate with moderate spines.

Remarks. D. perfecta has some of the characters of $D$. longa and $D$. perlaevis perlaevis. It is distinguished from $D$. longa by larger size, less elevated apical structure, and a more acute angle between struts and from $D$. perlaevis perlaevis by a narrower and less lobate ring and a relatively shorter bar.

Occurrence. $D$. perfecta is most numerous in lower Pliocene Cores 19,21 , and 23 of Hole 503A and ranges into the upper Pliocene. It is abundant $(45 \%)$ in Core 23 , where it displaced the local dominances of both $D$. longa and $D$. perlaevis perlaevis. As a part of the $D$. perlaevis group, $D$. perfecta may have been tabulated with $D$. perlaevis perlaevis in the past.

Size. Maximum inner diameter 35 to $45 \mu \mathrm{m}$ (holotype $41 \mu \mathrm{m}$ ).

Holotype. USNM 313056 (Plate 3, Fig. 5).

Isotypes. USNM 313057 to 313061 .

Type locality. Eastern equatorial Pacific, DSDP Sample 503A23-1 (120-121 cm).

Dictyocha transenna Bukry, n. sp.

(Plate 4, Figs. 1-12; Plate 5, Figs. 1, 2)

Description. Dictyocha transenna has a moderate-sized, fusiformoutlined ring with two spines at the apices along the major axis. A bar spans one end of the ring, dividing the central opening into one large and one small area. There are three principle varieties, based on the closeness of the bar to the apex. One form (A) has a straight bar farthest from the apex. A second (B) has a slightly curved bar closer to the apex, and a third $(C)$ has a curved bar right at the apex that leaves only the smallest vestigal opening. Some specimens show slight indentation of the ring at the bar junctions. The $\mathrm{L} / \mathrm{W}$ ratios range from 1.5 to 1.9. The bars of varieties A, B, C enclose, respectively, $73 \% / 27 \%$, $81 \% / 19 \%, 91 \% / 9 \%$. of the maximum inner diameter.

Remarks. $D$. transenna is distinguished from $D$. neonautica var. cocosensis, which also has an off-center bar, by the bar being much farther off-center and by the narrower, more fusiform outline of the ring. Extreme specimens of $D$. transenna $(C)$ approach Mesocena diodon nodosa in size and shape.

Occurrence. D. transenna occurs in Cores 32 to 34 in Hole 503A immediately above the acme of $D$. neonautica var. cocosensis. It is only abundant $(50 \%)$ in Core 34 , assigned to the late Miocene upper $D$. neonautica Subzone. Its acme presages that of $M$. diodon nodosa in the upper part of Core 34. It is not recorded above Core 30 in the lower Pliocene, and its presence in the lower Pliocene may be due to reworking. At Site 504, to the east, it is sparse in Sample 504-53-1 $(26-27 \mathrm{~cm})$.

Size. Maximum inner diameter 35 to $45 \mu \mathrm{m}$ (holotype $39 \mu \mathrm{m}$ ).

Holotype. USNM 313062 (Plate 4, Fig. 6).

Isotypes. USNM 313063 to 313075 .

Type locality. Eastern equatorial Pacific, DSDP Sample 503A-34$3(49-50 \mathrm{~cm})$.

\author{
Genus DISTEPHANUS Stohr, 1880 \\ Distephanus crux (Ehrenberg) Haeckel subsp. \\ carolae Bukry, n. subsp. \\ (Plate 5, Figs. 4-11)
}

Description. Distephanus crux carolae has a moderate-sized square basal ring with four pikes offset from the strut junctions. The spines are long and can be curved at the ends. The alignment of the majoraxis (longest) spines is distinctly offset across the center of the ring. The apical ring is moderate to small, and the struts join the basal ring asymmetrically. Fibuloid and asperoid variants with the same basal ring and spine morphology occur together with the more abundant, ringed forms.

Remarks. D. crux carolae is distinguished from D. crux crux of Ehrenberg (1854) by the distinctly offset major-axis spines and the presence of basal pikes. It is distinguished from D. stradneri of Jerković (see Loeblich and others, 1968) on the basis of holotypes by asymmetric instead of symmetric strut orientation, offset instead of aligned major-axis spines, and longer spines. The paratype figure of $D$. stradneri appears to be a different form more closely allied with $D$. crux carolae, but the spine offset and pikes are not very pronounced.

Occurrence. $D$. crux carolae is a minor species in Cores 36 and in Cores 39 to 41 in Hole 503A in the upper Miocene Dictyocha fibula Zone in the interval between the upper and lower $D$. neonautica subzone. Ringed forms predominate, and fibuloid variants outnumber asperoid variants.

Size. Maximum inner diameter 22 to $26 \mu \mathrm{m}$ (holotype $25 \mu \mathrm{m}$ ).

Holotype. USNM 313076 (Plate 5, Fig. 6).

Isotypes. USNM 313077 to 313083 .

Type locality. Eastern equatorial Pacific, DSDP Sample 503A40-1 (83-84 cm).

\section{Distephanus speculum (Ehrenberg) Haeckel subsp. bispicatus Bukry, n. subsp. \\ (Plate 6, Figs. 2-4)}

Distephanus speculum (Ehr.), Dumitrică, 1973a (in part), p. 908, pl. 10 , figs. 7 and 11 .

Description. Distephanus speculum bispicatus has a hexagonal basal ring with six spines and up to six pikes; the two major-axis spines are the longest. The rounded hexagonal apical ring has two pikes aligned with the major-axis spines and rising distally above the plane of the apical ring.

Remarks. D. speculum bispicatus is distinguished from $D$. speculum speculum by two pikes on the apical ring. It is distinguished from $D$. speculum f. coronata of Schulz (see Loeblich and others, 1968) by having only two instead of six apical pikes. At first inspection, some specimens of $D$. speculum bispicatus may appear to be $D$. speculum $\mathrm{f}$. coronata, because the basal ring pikes line up with the directions where pikes on the apical ring would be located. Because apical pikes are a feature of several Neogene taxa of Distephanus such as $D$. quinquangellus, taxonomic distinction may be questionable. Although tabulation, for Hole 503A, of D. speculum bispicatus and D. speculum speculum showed similar ranges here, there are increased proportions of $D$. speculum bispicatus upward through the upper Miocene to Pliocene section.

Occurrence. $D$. speculum bispicatus ranges through Hole 503A from Cores 12 to 54, in the upper Pliocene to upper Miocene. Typical abundances are 1 to $4 \%$, with maximum values of 11 to $15 \%$. Its first and last occurrence cannot be determined from this study. Poelchau (1976) shows it from the Holocene of the North Pacific.

Size. Maximum inner diameter 18 to $25 \mu \mathrm{m}$ (holotype $21 \mu \mathrm{m}$ ). Holotype. USNM 313084 (Plate 6, Fig 2). 
Isotypes. USNM 313085 to 313086

Type locality. Eastern equatorial Pacific, DSDP Sample 503A33-1 $(88-89 \mathrm{~cm})$.

\section{Distephanus speculum (Ehrenberg) Haeckel subsp. tenuis Bukry, $\mathrm{n}$. subsp. \\ (Plate 6, Figs. 5-11).}

Description. Distephanus speculum tenuis has a hexagonal ring with short to moderate spines and short basal pikes. The six struts and wide hexagonal apical ring are distinctly thinner than the basal ring. On many specimens the apical structure is partly broken away.

Remarks. D. speculum tenuis is distinguished from $D$. speculum speculum by the delicate structure of the apical ring and struts. It is distinguished from hexagonal variants of Octactis pulchra (see Bukry, 1979a, pl. 5, figs. 12, 13) by the presence of basal pikes (H. S. Poelchau, verbal communication, 1974).

Occurrence. The range of $D$. speculum tenuis is contained within the upper Miocene and lower Pliocene of Cores 29 to 50. It is most common (1 to $6 \%$; max., 17\%) in the upper Miocene interval between the two parts of the Dictyocha neonautica Subzone.

Size. Maximum inner diameter 20 to $25 \mu \mathrm{m}$ (holotype $20 \mu \mathrm{m}$ ).

Holotype. USNM 313087 (Plate 6, Fig. 5).

Isotypes. USNM 313088 to 313091 .

Type locality. Eastern equatorial Pacific, DSDP Sample 503A48-2 $(82-83 \mathrm{~cm})$.

\section{GUIDE TO SYSTEMATIC PALEONTOLOGY OR ILLUSTRATION REFERENCE FOR PREVIOUSLY CITED TAXA}

Corbisema triacantha (Ehrenberg) Hanna-Bukry, 1979a.

Dictyocha aculeata (Lemmermann) Dumitrică-Bukry, 1980.

D. angulata Bukry-Bukry, in press.

D. aspera aspera (Lemmermann) Bukry and Foster-Bukry, 1980.

D. aspera clinata Bukry-Bukry, 1975.

D. brevispina (Lemmermann) Bukry-Bukry, 1981b.

D. calida Poelchau-Poelchau, 1976.

D. concavata Dumitrică-Bukry, 1981b.

D. delicata (Bukry) Bukry-Bukry, in press.

D. delicata var. bisecta Bukry-Bukry, in press.

D. fibula Ehrenberg-Bukry, in press.

D. longa Bukry-Bukry, in press.

D. longa var. paxilla Bukry-Bukry, in press.

D. neonautica Bukry-Bukry, in 1981a.

D. neonautica var. cocosensis Bukry-Bukry, 1981a.

D. ornata africana Bukry-Bukry, in press.

D. ornata ornata (Bukry) Bukry-Bukry, in press.

D. pentagona (Schulz) Bukry and Foster-Bukry and Foster, 1973.

D. perlaevis flexatella Bukry-Bukry, 1979b.

D. perlaevis perlaevis Frenguelli-Bukry, 1979b.

D. pulchella Bukry-Bukry, 1981 b.

D. stapedia aspinosa Bukry-Bukry, 1980.

D. stapedia stapedia Haeckel-Bukry, 1979b.

D. subaculeata (Bukry) Bukry-Bukry, 1980.

D. varia Locker-Bukry, $1981 \mathrm{~b}$.

Distephanus boliviensis boliviensis (Frenguelli) Bukry and Foster-Bukry, 1980.

D. boliviensis major (Frenguelli) Bukry-Bukry, 1979a.

D. crux bispinosus Dumitrică-Dumitrică, 1973b.

D. crux crux (Ehrenberg) Haeckel-Bukry, in press.

D. frugalis (Bukry) Bukry-Bukry, 1979a.

D. mesophthalmus (Ehrenberg) Haeckel-Bukry, in press.

D. polyactis (Ehrenberg) Deflandre-Bukry and Foster, 1973.

D. quinquangellus Bukry and Foster-Bukry, in press.

D. speculum elongatus Bukry-Bukry, 1981b.

D. speculum minutus (Bachmann) emend. Bukry-Bukry, in press.

D. speculum speculum (Ehrenberg) Haeckel-Bukry, 1980. Mesocena circulus (Ehrenberg) Ehrenberg-Bukry, 1980.

M. diodon nodosa Bukry-Bukry, 1981b.

M. quadrangula Ehrenberg ex Haeckel-Bukry, 1980.

M. triodon Bukry-Bukry, 1981b.

\section{ACKNOWLEDGMENTS}

I thank Dorothy L. Blackstock, U.S. Geological Survey, for preparing the figures and typing the manuscript. John A. Barron, U.S.
Geological Survey, provided helpful discussion on Pacific paleontology during the study. James V. Gardner, U.S. Geological Survey, and Charles G. Adelseck and Linda Garifal, both of Deep Sea Drilling Project, provided help in obtaining samples and information about Leg 68. I thank Richard Z. Poore and John A. Barron, U.S. Geological Survey, for helpful reviews of the manuscript.

\section{NOTE ADDED IN PROOF}

\section{On the Utility of an Asperoid/Fibuloid Ratio}

A reversal between asperoid and fibuloid dominance among Dictyocha species was recently calibrated as isochronous at about $7.4 \mathrm{Ma}$ for the equatorial and northeastern Pacific (DSDP Site $173,39^{\circ} \mathrm{N}$ ) by Burckle (1981). But at equatorial DSDP Hole 503A there are six different Asperoid/Fibuloid (A/F) reversals between 7.4 Ma and 5.0 Ma in the interval from Core 54 to Core 30. Also, at equatorial Site 504 of Leg 69, the earliest reversal, at about $7.0 \mathrm{Ma}$, is reversed again slightly later in the late Miocene. An abundance of cool-water Distephanus speculum in the asperoid-rich intervals indicates that late Miocene short-term cooling events at DSDP Sites 504,472 , and 469 probably promote the asperoid taxa of Dictyocha.

Newly published data from DSDP Site $464\left(39^{\circ} \mathrm{N}\right.$, Hess Rise) show that asperoid dominance in the $\mathrm{A} / \mathrm{F}$ ratio extends into the early Pliocene and then reverses more than once (Müller, 1981; see also Bukry, 1978). These occurrences contradict the utility of a single isochronous 7.4 Ma Miocene A/F event for the equatorial and North Pacific. Therefore the first $D$. longa has been proposed to replace the $A / F$ reversal as the boundary criterion for the base of the Dictyocha fibula Zone (Bukry, in press).

\section{References}

Bukry, D., 1978. Cenozoic silicoflagellate and coccolith stratigraphy, southeastern Atlantic Ocean, Deep Sea Drilling Project Leg 40. In Bolli, H. M., Ryan, W. B. F., et al., Init. Repts. DSDP, 40: Washington (U.S. Govt. Printing Office), 635-649.

in press. Upper Cenozoic silicoflagellates from offshore Ecuador, Deep Sea Drilling Project Site 504. In Langseth, M. G., Cann, J. R., et al., Init. Repts. DSDP, 69: Washington (U.S. Govt. Printing Office).

Burckle, L. H., 1981. Paleomagnetic data on the Dictyocha aspera/ fibula crossover in the equatorial Pacific. Micropaleontology, 27: 332-334.

Müller, C., 1981. Miocene to Pleistocene silicoflagellates from the central North Pacific, Deep Sea Drilling Project Leg 62. In Thiede, J., Vallier, T. L., et al., Init. Repts. DSDP, 62: Washington (U.S. Govt. Printing Office), 361-364.

\section{REFERENCES}

Bukry, D., 1975. Coccolith and silicoflagellate stratigraphy, northwestern Pacific Ocean, Deep Sea Drilling Project Leg 32. In Larson, R. L., Moberly, R., et al., Init. Repts. DSDP, 32: Washington (U.S. Govt. Printing Office), 677-701.

1979a. Coccolith and silicoflagellate stratigraphy, northern Mid-Atlantic Ridge and Reykjanes Ridge, Deep Sea Drilling Project Leg 49. In Luyendyk, B. P., Cann, J. R., et al., Init. Repts. DSDP, 49: Washington (U.S. Govt. Printing Office), 551-581. $1979 \mathrm{~b}$. Comments on opal phytoliths and stratigraphy of Neogene silicoflagellates and coccoliths at Deep Sea Drilling Project Site 397 off northwest Africa. In Luyendyk, B. P., Cann, J. R., et al., Init. Repts. DSDP, 49: Washington (U.S. Govt. Printing Office), $977-1009$.

1980. Silicoflagellate biostratigraphy and paleoecology in the eastern equatorial Pacific, Deep Sea Drilling Project Leg 54. In Rosendahl, B. R., Hekinian, R., et al., Init. Repts. DSDP, 54: Washington (U.S. Govt. Printing Office), 545-573. 1981a. Synthesis of silicoflagellate stratigraphy for Maestrichtian to Quaternary marine sediment. Soc. Econ. Paleontol. Mineral (Am. Assoc. Petrol Geol.). Spec. Publ., 32:335-353. , 1981b. Silicoflagellate stratigraphy of offshore California and Baja California, Deep Sea Drilling Project Leg 63. In Yeats, R. S., Haq, B. U., et al., Init. Repts. DSDP, 63: Washington (U.S. Govt. Printing Office), 539-558.

, in press. Cenozoic silicoflagellate from offshore Guatemala, Deep Sea Drilling Project Site 495. In von Huene, R. 
Aubouin, J., et al., Init. Repts. DSDP, 67: Washington (U.S. Govt. Printing Office).

Bukry, D., and Foster, J. H., 1973. Silicoflagellate and diatom stratigraphy, Leg 16, Deep Sea Drilling Project. In van Andel. Tj. H., Heath, G. R., et al., Init. Repts. DSDP, 16: Washington (U.S. Govt. Printing Office), 815-871.

Deflandre, G., 1941. Les notions de genre et de grade chez les Silicoflagellidées et la phylogenèse des mutants naviculaires. C. R. Acad. Sci., 212:100-102.

Dumitrică, P., 1973a. Miocene and Quaternary silicoflagellates in sediments from the Mediterranean Sea. In Ryan, W. B. F., Hsü, K. J., et al., Init. Repts. DSDP, 13: Washington (U.S. Govt. Printing Office), 902-933.

, 1973b. Paleocene, late Oligocene and post-Oligocene silicoflagellates in southwestern Pacific sediments cored on DSDP Leg
21. In Burns, R. E., Andrews, J. E., et al., Init. Repts. DSDP, 21: Washington (U.S. Govt. Printing Office), 837-883.

Ehrenberg, C. G., 1854. Mikrogeologie: Leipzig, (Leopold Voss), pp. 1-374.

Ichikawa, W., 1973. Silicoflagellates and ebridians in the surface mud from the Toyama Bay and the Hiruga Lake along the coast of the Hokuriku District, Japan-In comparison with those of the Japan Sea mud. Kanazawa Univ. Jpn. Sea Res. Inst. Bull., 5:1-15.

Loeblich, A. R., III, Loeblich, L. A., Tappan, H., and Loeblich, A. R. Jr., 1968. Annotated index of fossil and recent silicoflagellates and ebridians with descriptions and illustrations of validly proposed taxa. Geol. Soc. Am. Mem., 106:1-319.

Poelchau, H. S., 1976. Distribution of Holocene silicoflagellates in North Pacific sediments. Micropaleontology, 22:164-194. 


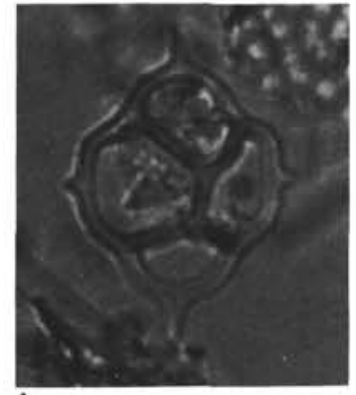

1
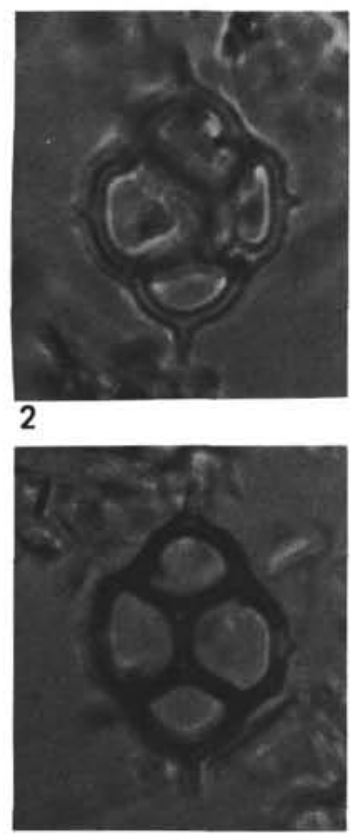

3

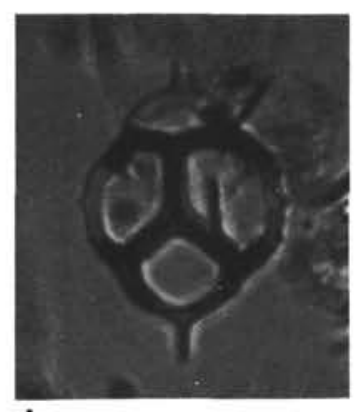

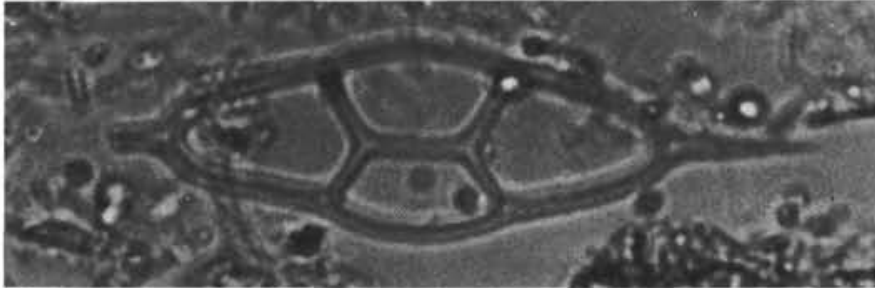

5

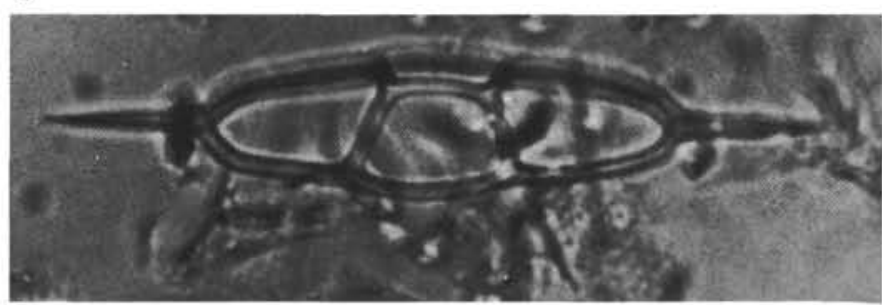

\section{6}

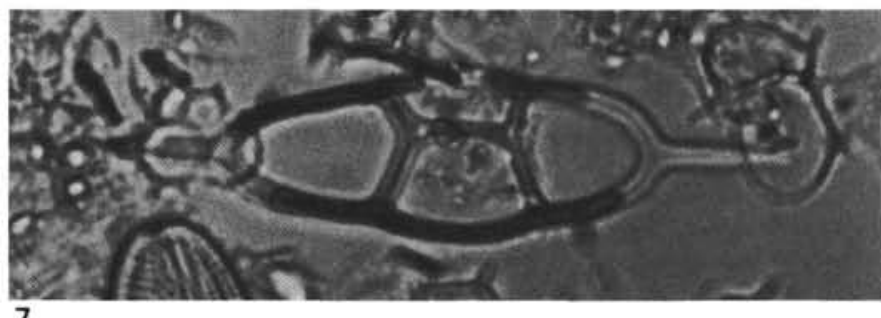

7

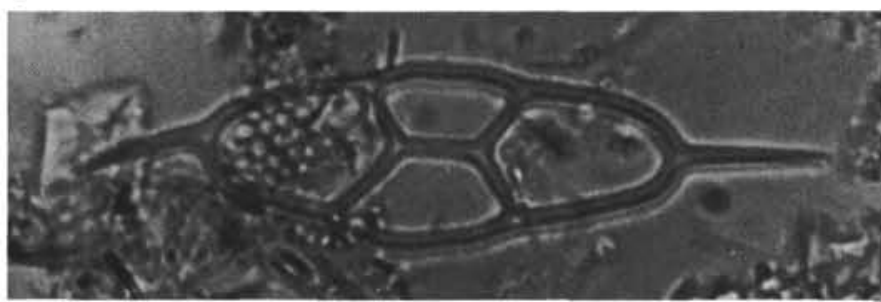

\section{8}

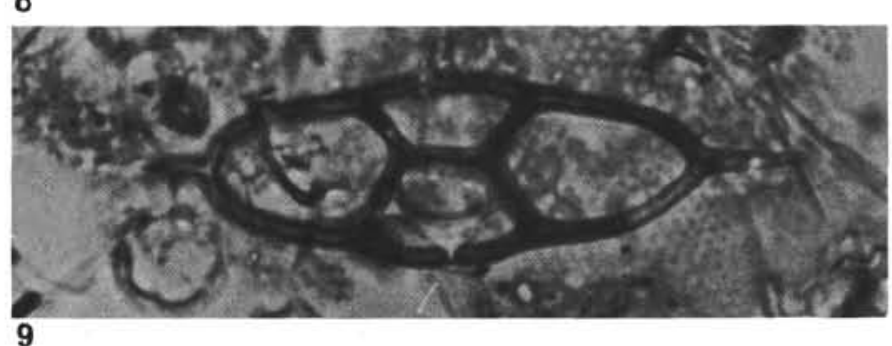

9

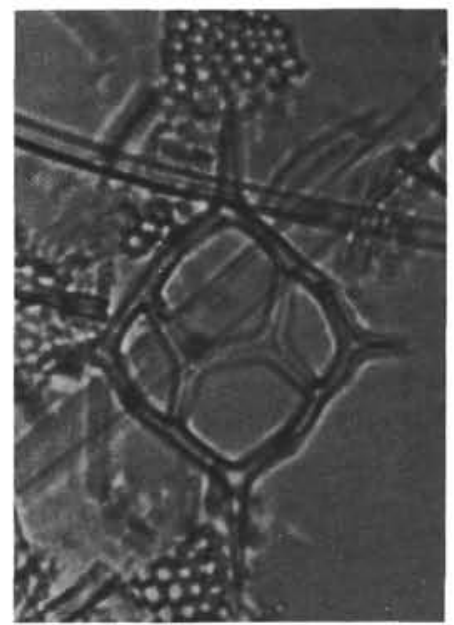

10

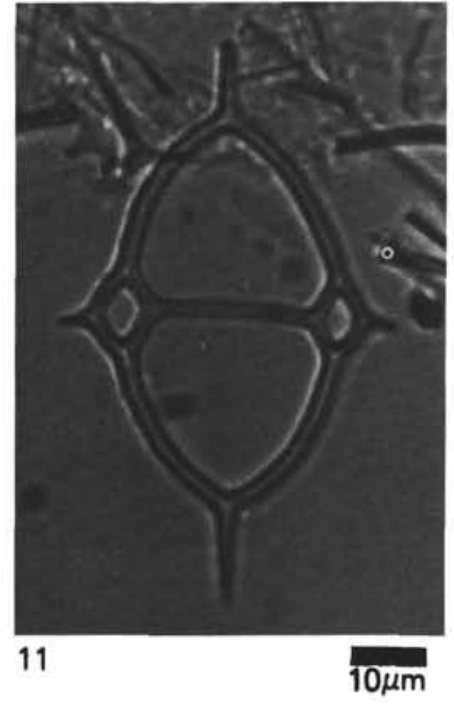

4

Plate 1. Silicoflagellates from DSDP Hole 503A. Magnification $\times 800$; scale bar equals $10 \mu \mathrm{m} .1-4$. Dictyocha angulata Bukry. All specimens from Sample 503A-21-1 (133-134 cm). $(1,2)$ Same specimen, high and low focus. 5-9. Dictyocha arbutusensis Bukry, $\mathrm{n}$. sp. All specimens from Sample 503A-13-3 (66-67 cm). (5) Holotype, USNM 313051, (6) USNM 313052, tilted, (7) USNM 313053, (8) USNM 313054, (9) USNM 313055. 10. Dictyocha sp. aff. D. aspera clinata Bukry. Sample 503A-37-1 (102-103 cm). 11. Dictyocha brevispina (Lemmermann) (elongate). Sample 503A-48-3 (20-21). 


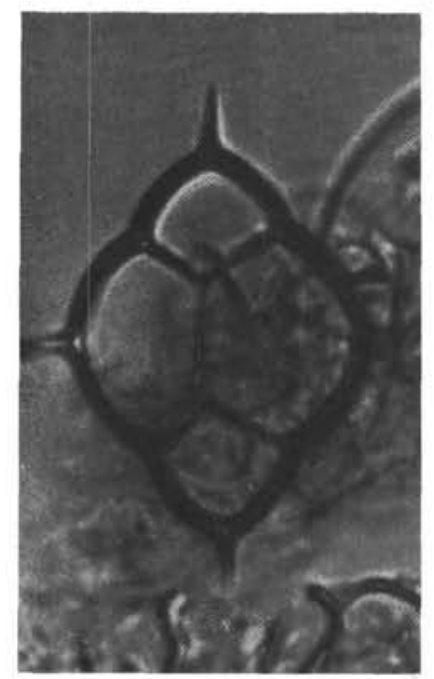

1

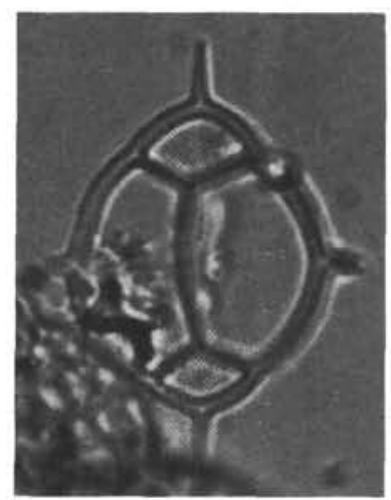

4

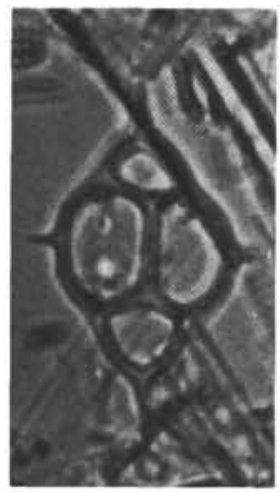

8

9

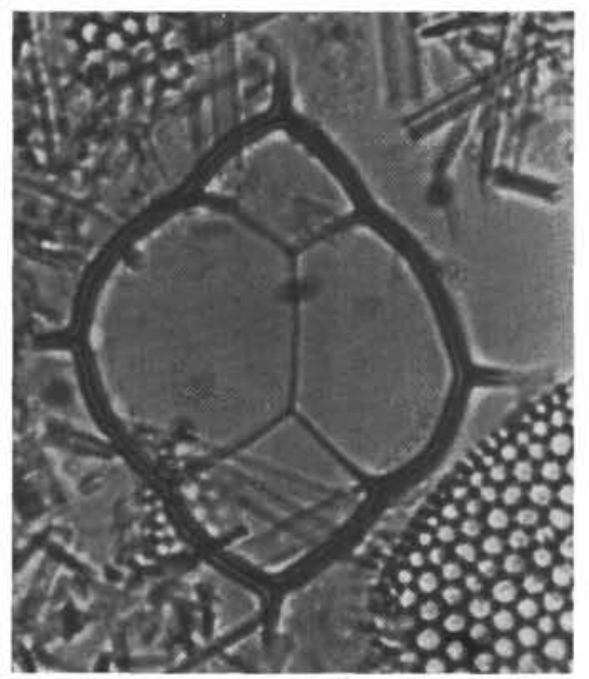

2

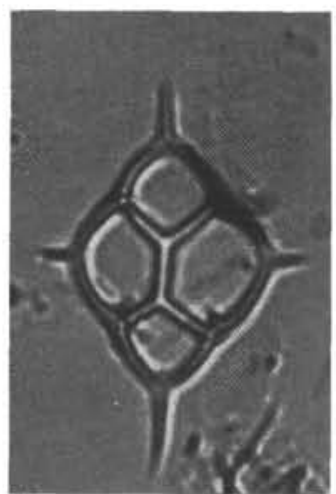

5

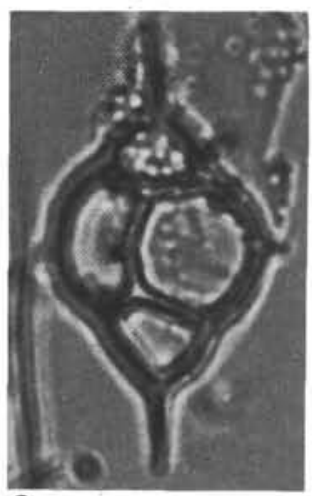

6

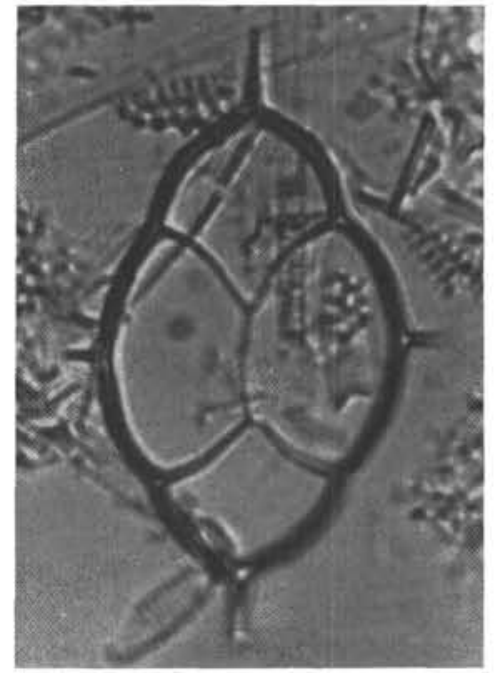

3
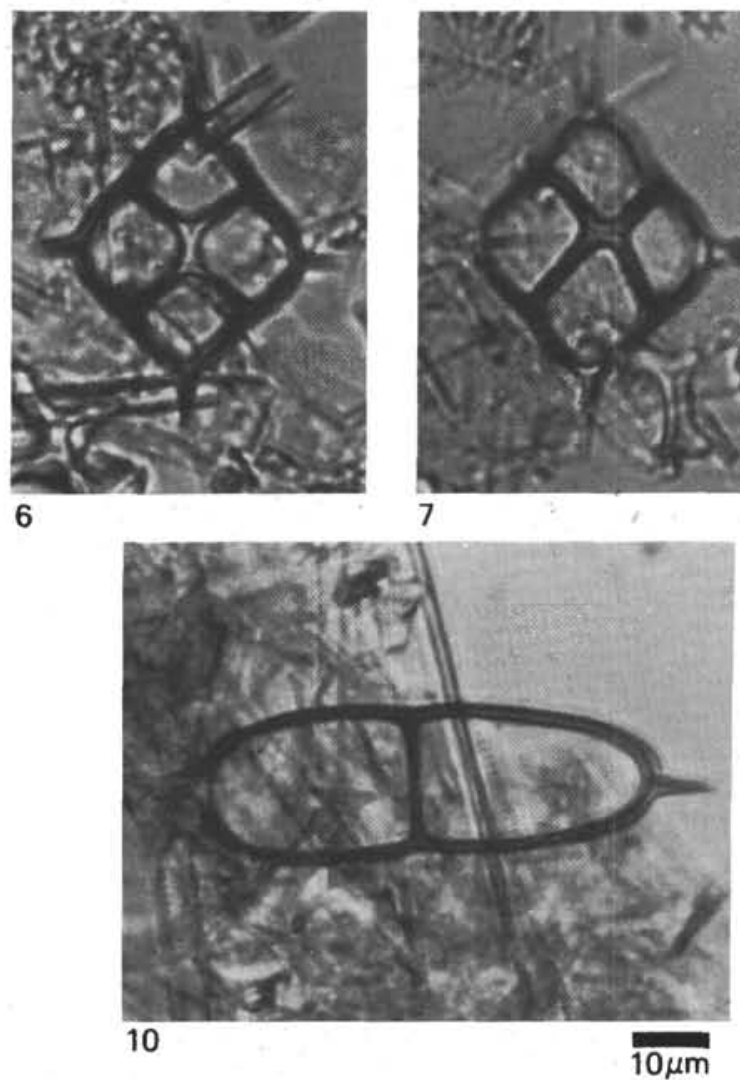

Plate 2. Silicoflagellates from DSDP Hole 503A. Magnification $\times 800$; scale bar equals $10 \mu \mathrm{m}$. 1-3. Dictyocha delicata (Bukry). (1) Normal. Sample 503A-20-1 (104-105 cm). (2, 3) Large. Sample 503A-30-1 (66-67 cm). 4. Dictyocha delicata var. bisecta Bukry, Sample 503A-16-2 (120$121 \mathrm{~cm})$. 5. Dictyocha fibula Ehrenberg s. ampl. Sample 503A-42-3 $(70-71 \mathrm{~cm})$. 6, 7. Dictyocha sp. cf. D. fibula Ehrenberg (angular with short bar). Sample 503A-51-2 (63-64 cm). (6) Fibuloid, (7) Asperoid, 8. Dictyocha longa Bukry, Sample 503A-42-3 (70-71 cm). 9. Dictyocha longa var. paxilla Bukry. Sample 503A-42-3 (70-71 cm). 10. Dictyocha neonautica Bukry. Sample 503A-34-2 $(36-37 \mathrm{~cm})$. 


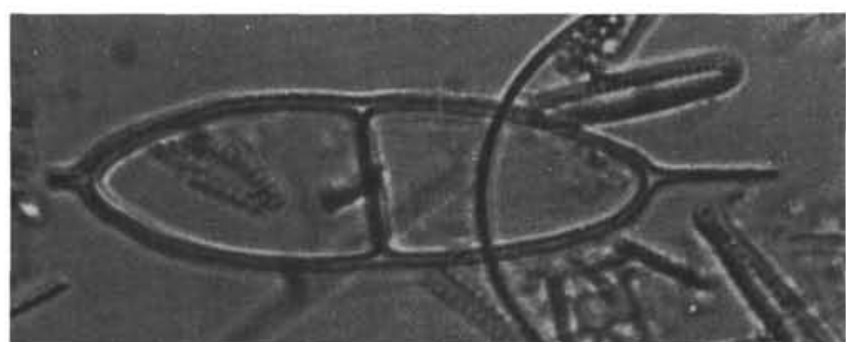

1

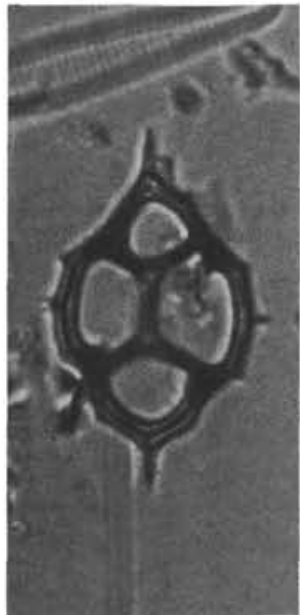

3

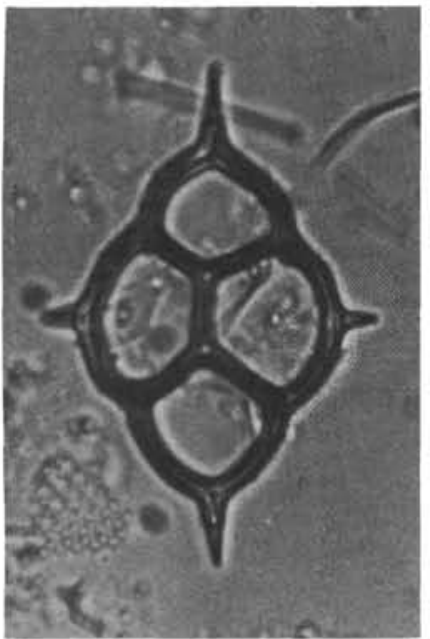

7

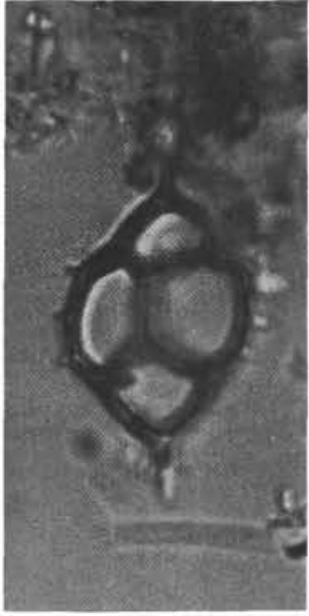

4

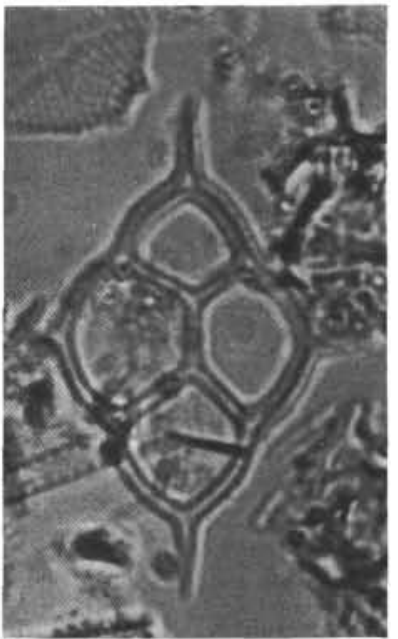

8

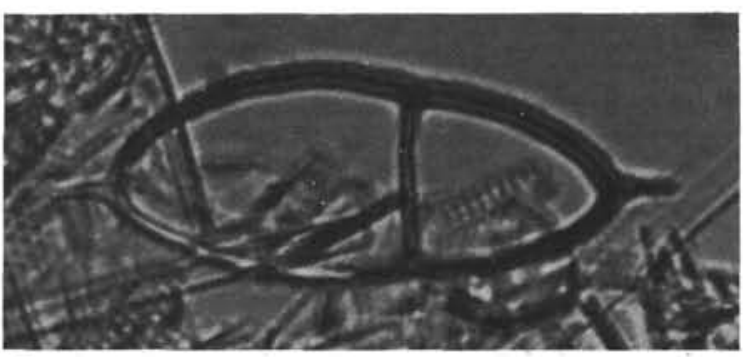

2
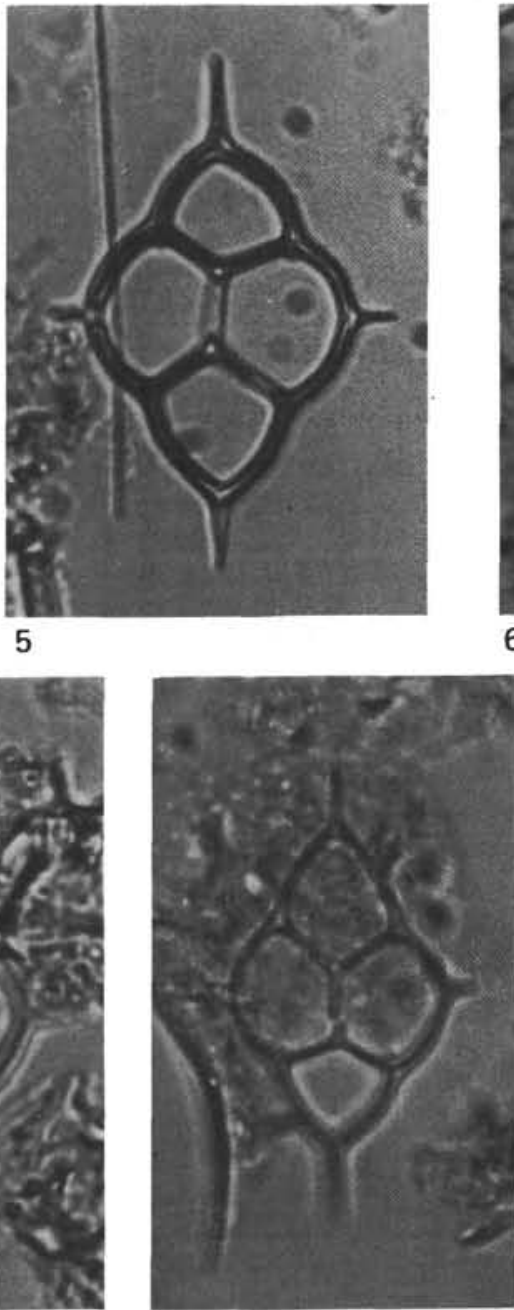

9

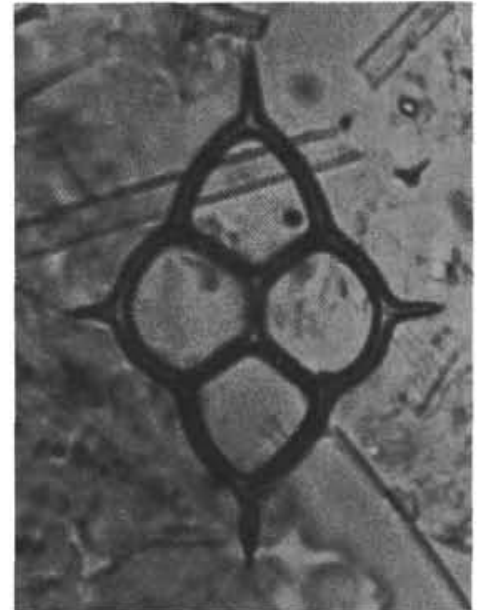

6

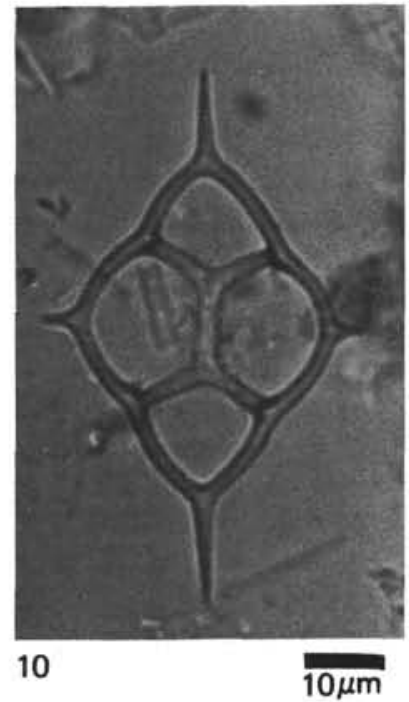

Plate 3. Silicoflagellates from DSDP Hole 503A. Magnification $\times 800$; scale bar equals $10 \mu \mathrm{m}$. 1. Dictyocha neonautica Bukry. Sample 503A-34-2 (110-111 cm). 2. Dictyocha neonautica var. cocosensis Bukry (elongate). Sample 503A-34-3 (49-50 cm). 3. Dictyocha ornata africana Bukry. Sample 503A-14-2 (21-22 cm). 4. Dictyocha sp. aff. D. ornata africana Bukry. Sample 503A-14-2 (21-22 cm). 5-10. Dictyocha perfecta Bukry, n. sp. (5) Holotype, USNM 313056, Sample 503A-23-1 (120-121 cm), (6) USNM 313057, Sample 503A-21-1 (133-134 $\mathrm{cm})$, (7) USNM 313058, Sample 503A-23-1 (120-121 cm), (8) USNM 313059, Sample 503A-21-1 (133-134 cm), (9) USNM 313060, Sample 503A-19-2 (124-125 cm), (10) USNM 313061, Sample 503A-23-1 (120-121 cm). 


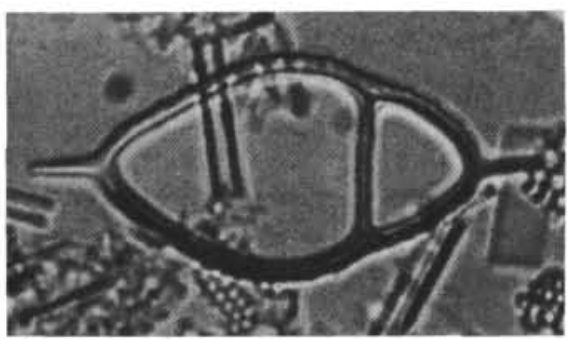

1

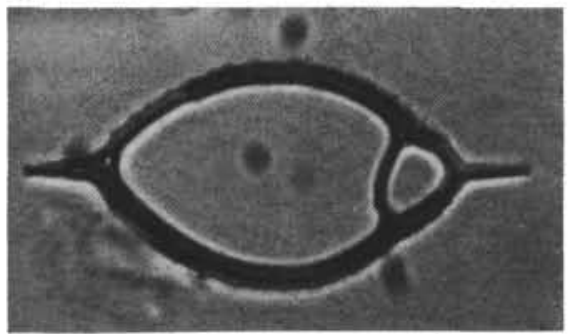

4

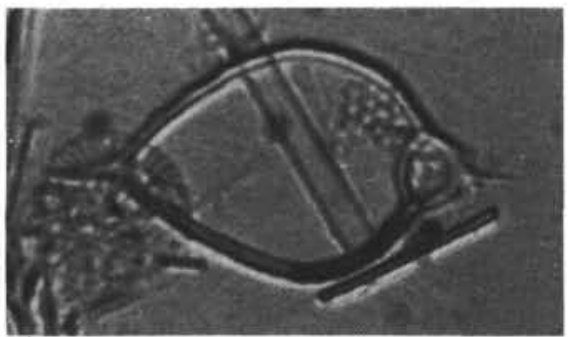

7

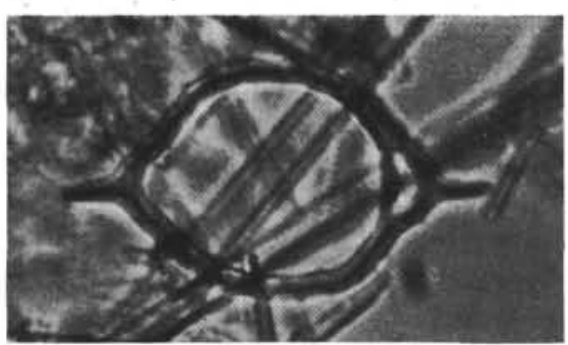

10

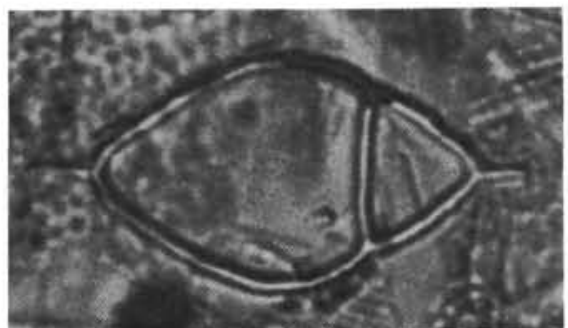

2

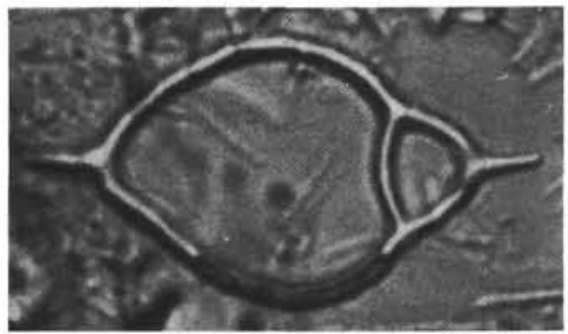

5

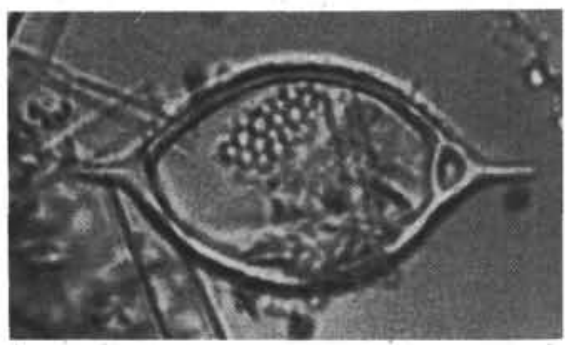

8

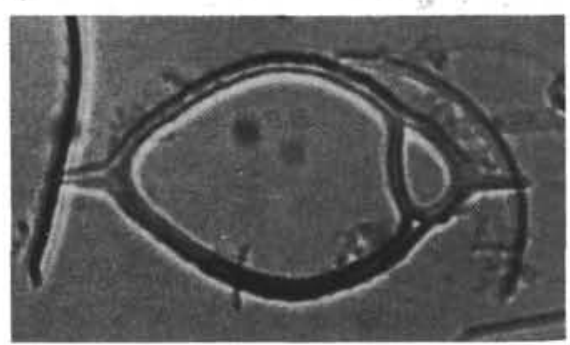

11

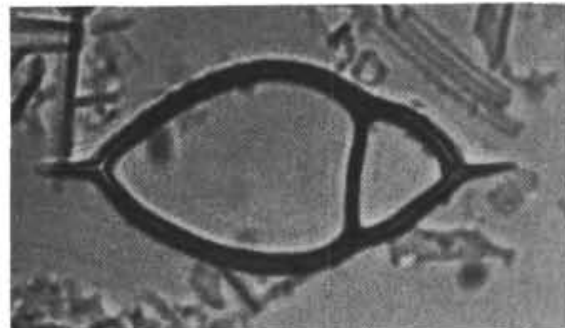

3

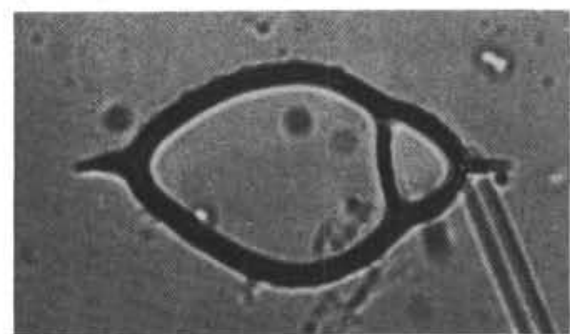

6

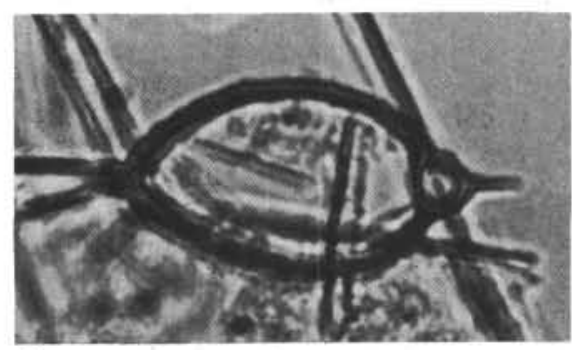

9

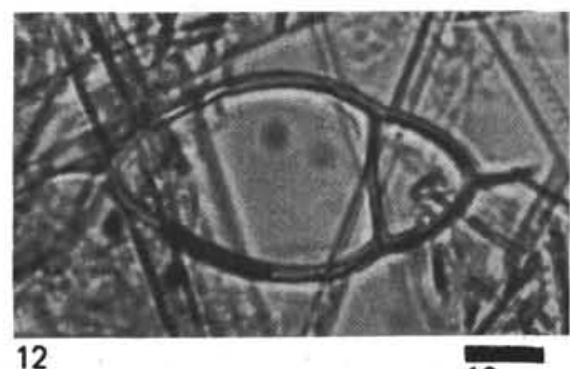

$10 \mu \mathrm{m}$

Plate 4. Silicoflagellates from DSDP Hole 503A. Magnification $\times 800$; scale bar equals $10 \mu \mathrm{m}$. All specimens from Sample 503A-34-3 (49-50 cm) except Figures 4 and 10, which are from Sample 503A-34-2 (36-37 cm). 1-12. Dictyocha transenna Bukry, n. sp. Three major categories based on bar position are informally grouped as Types A, B, and C. In Hole 503A Type B is most numerous and A the least numerous. (1) USNM 313063, A, (2) USNM 313064, A, (3) USNM 313065, A, (4) USNM 313066, B, (5) USNM 313067, B, (6) Holotype, USNM 33062, B, (7) USNM $313068, \mathrm{C},(8)$ USNM 313069, C, (9) USNM 313070, C, (10) USNM 313071, C hexagonal, (11) USNM 313072, B, (12) USNM 313073, A. 


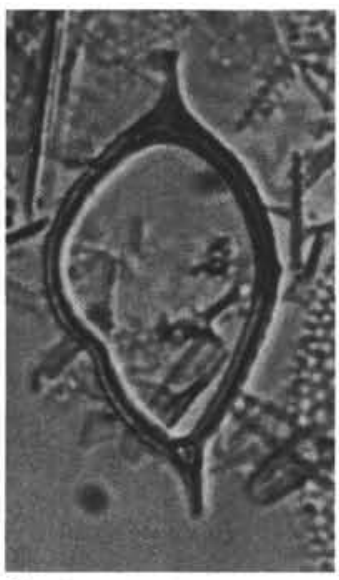

1

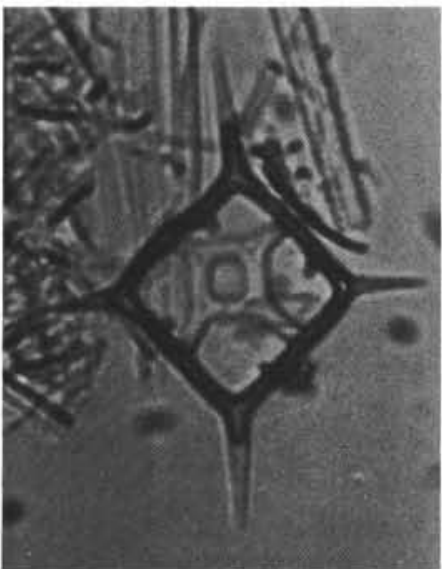

5

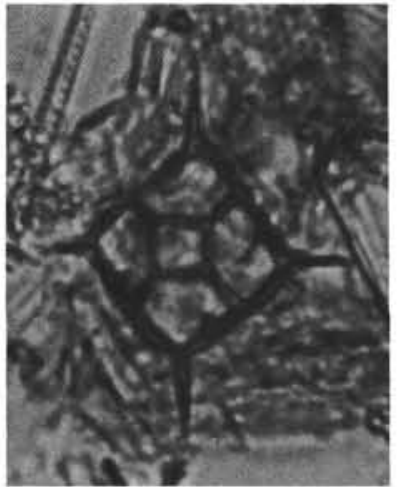

8

2

9
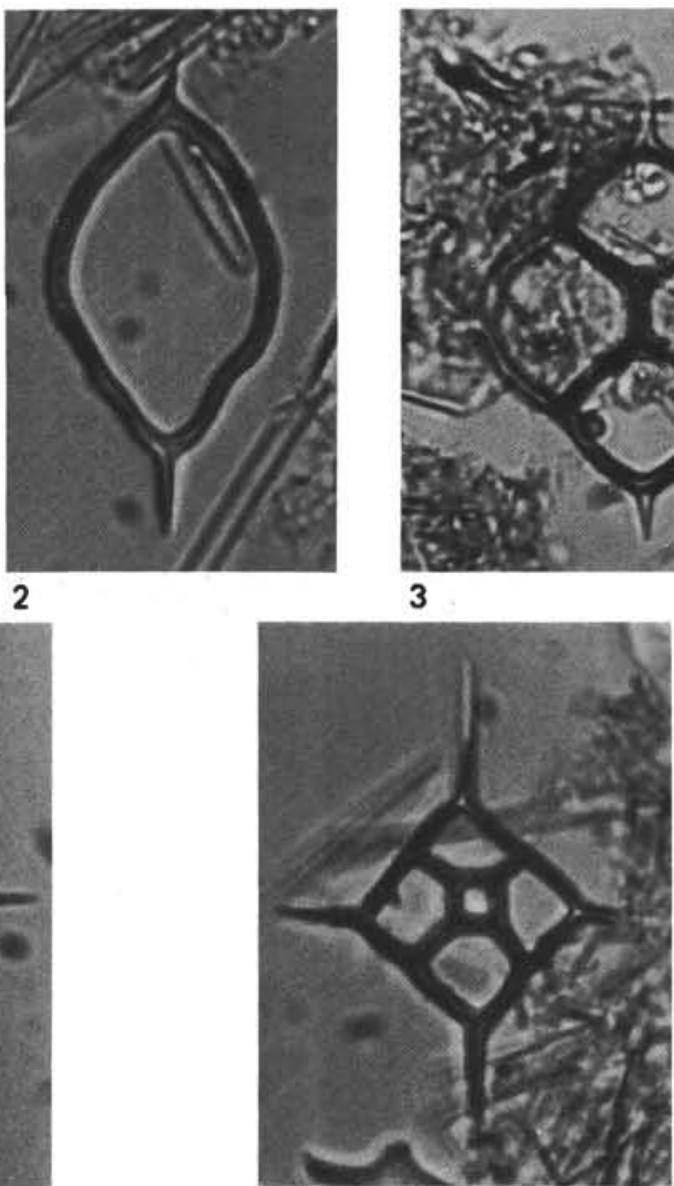

6

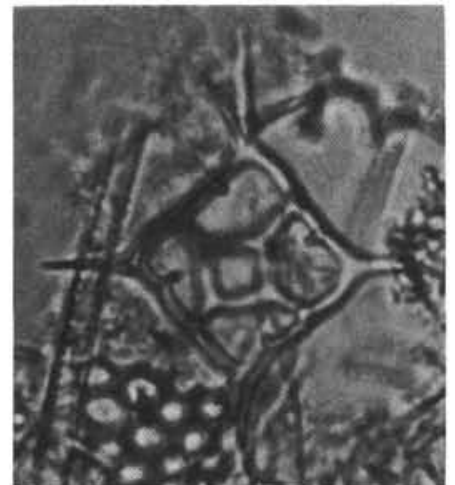

3

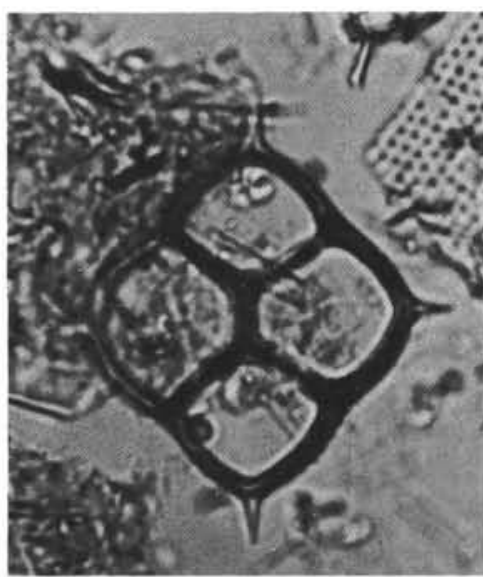

\section{4}

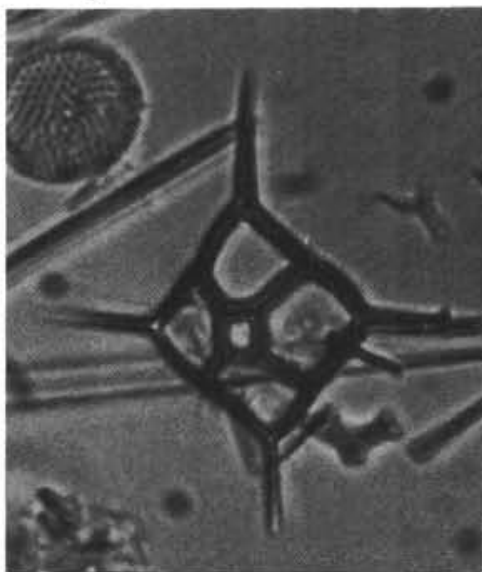

7

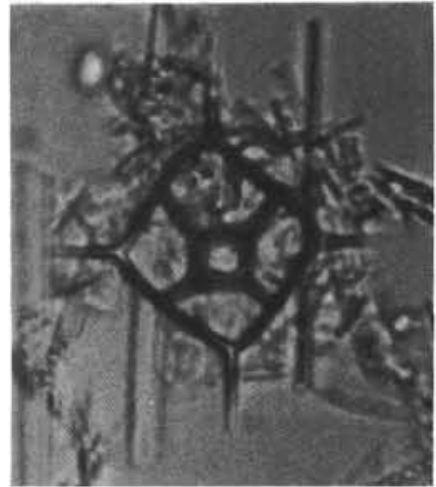

10

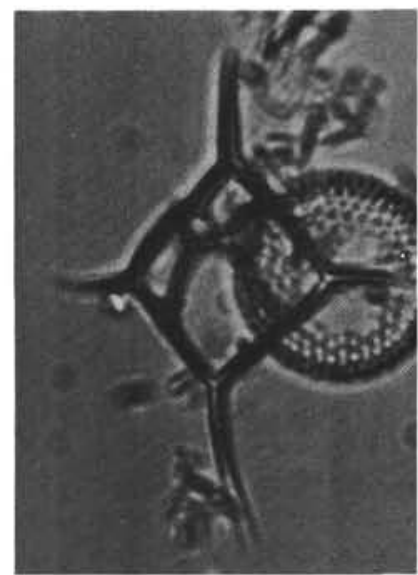

4

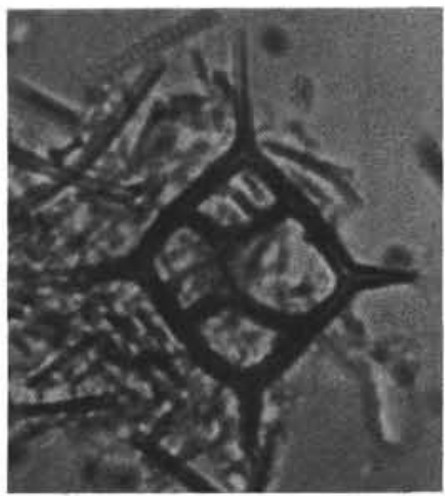

11
$10 \mu \mathrm{m}$

Plate 5. Silicoflagellates from DSDP Hole 503A. Magnification $\times 800$; scale bar equals $10 \mu \mathrm{m} . \quad 1$. Dictyocha transenna Bukry, n. sp., USNM 313074, C, transitional to Mesocena, Sample 503A-34-2 (110-111 cm). 2. ?Dictyocha transenna Bukry, n. sp., USNM 313075, C, ring form compatible but bar missing, a probable link to Mesocena, Sample 503A-34-3 (49-50 cm). 3. Dictyocha sp. A, Sample 503A-13-2 (21-22 $\mathrm{cm})$. 4-11. Distephanus crux carolae Bukry, subsp. (4) USNM 313077, asperoid variant, Sample 503A-41-1 (34-35 cm), (5) USNM 313078, abapical, Sample 503A-41-1 (34-35 cm), (6) Holotype, USNM 313076, Sample 503A-40-1 (83-84 cm), (7) USNM 313079, Sample 503A-40-1 (83-84 cm), (8) USNM 313080, abapical, Sample 503A-39-2 (137-138 cm), (9) USNM 313081, abapical, Sample 503A-37-1 (102-103 cm), (10) USNM 313082, Sample 503A-39-2 (137-138 cm), (11) USNM 313083, fibuloid, Sample 503A-40-1 (83-84 cm). 


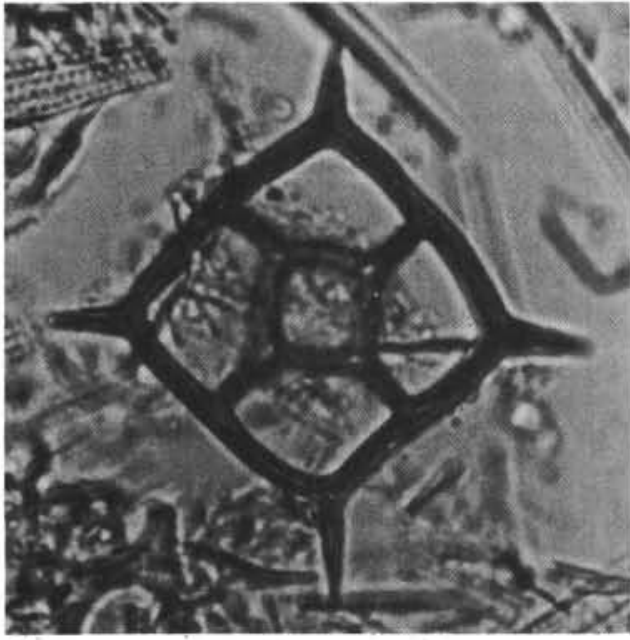

1

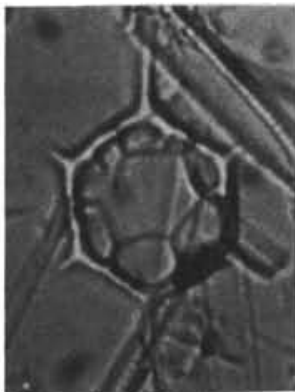

5

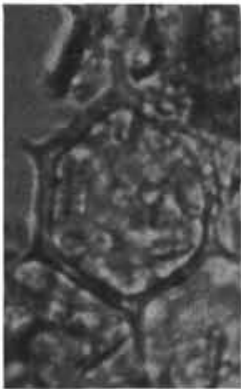

10

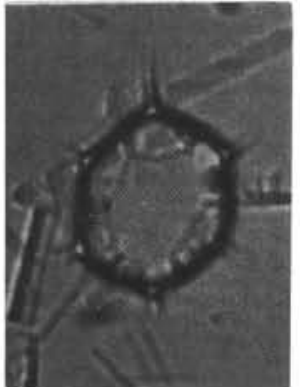

6

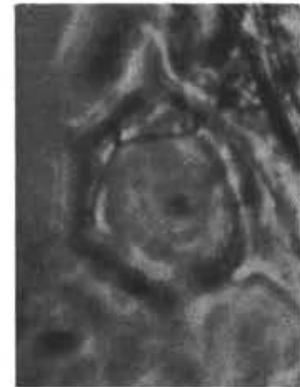

11

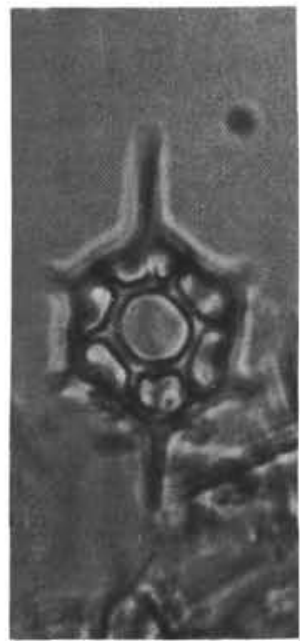

2

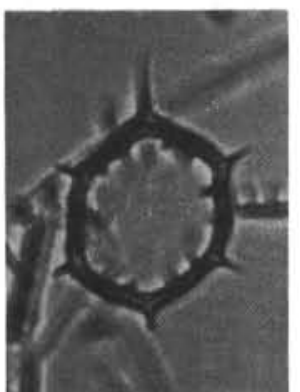

7

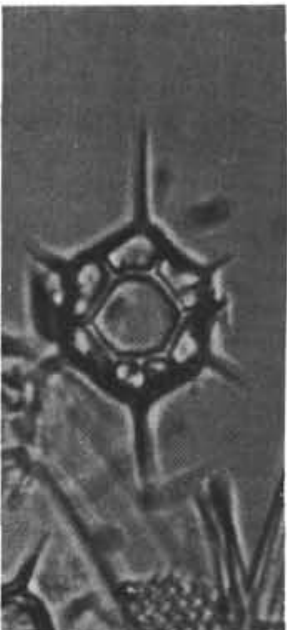

3

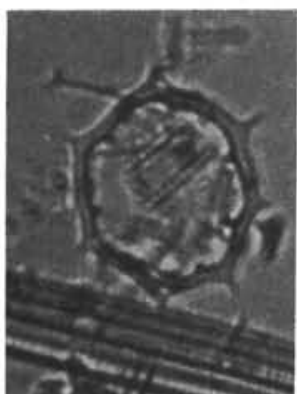

8

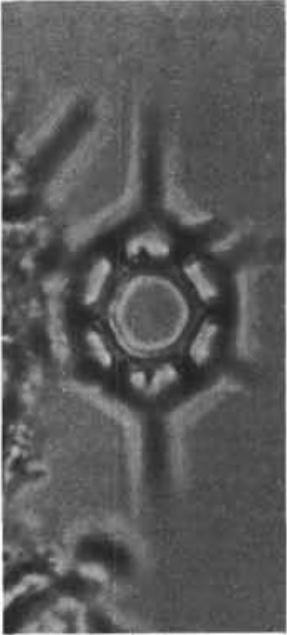

4

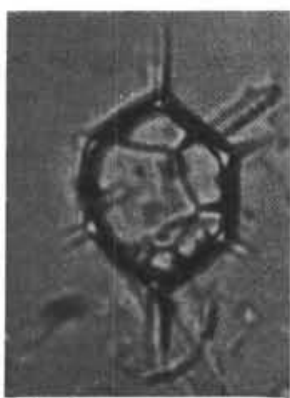

9

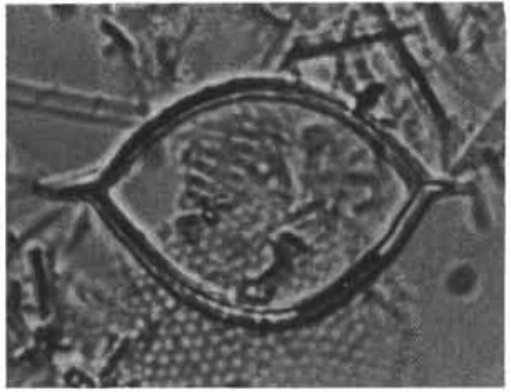

12

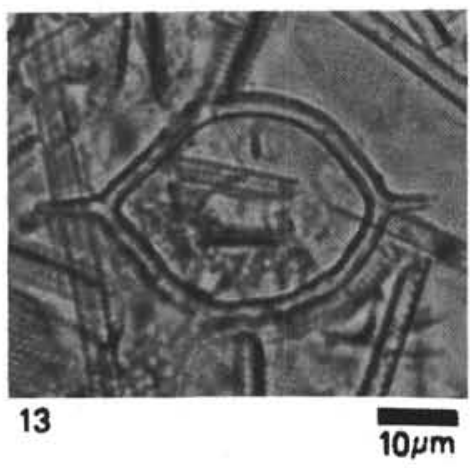

Plate 6. Silicoflagellates from DSDP Hole 503A. Magnification $\times 800$; scale bar equals $10 \mu \mathrm{m} .1$. Distephanus crux crux (Ehrenberg) (large). Sample 503A-33-1 (88-89 cm). 2-4. Distephanus speculum bispicatus Bukry, n. subsp. (2) Holotype, USNM 313084, Sample 503A-33-1 (88-89 $\mathrm{cm})$, (3) USNM 313085, Sample 503A-43-3 (6-7 cm), (4) USNM 313086, Sample 503A-32-1 (60-61 cm). 5-11. Distephanus speculum tenuis Bukry, n. subsp. (5) Holotype, USNM 313087, Sample 503A-48-2 (82-83 cm). (6, 7) USNM 313088, apical and basal focus, Sample 503A-43-3 $(6-7 \mathrm{~cm}),(8)$ USNM 313089, heptagonal, Sample 503A-37-1 (102-103 cm), (9) USNM 313090, Sample 503A-48-1 (80-81 cm). (10, 11) USNM 313091 , basal and apical focus, Sample 503A-37-1 (102-103 cm). 12, 13. Mesocena diodon nodosa Bukry. (12) Sample 503A-34-2 (110-111 $\mathrm{cm})$, (13) hexagonal variation (compare to hexagonal Dictyocha transenna), Sample 503A-34-2 (110-111 cm). 